\title{
Comparison of APACHE II and Modified Charlson Index in Mortality Prediction in Patients at Medical Intensive Care Unit
}

\section{${ }^{1}$ Oktay Bulur, ${ }^{1}$ Fatma Kaplan Efe, ${ }^{1}$ Hatice Kevser Ispir Iynem, ${ }^{2}$ Suleyman Koc, ${ }^{1}$ Esin Beyan}

${ }^{1}$ Health Sciences University Keciören

Training and Research Hospital Internal Medicine Clinic, Ankara, Turkey

${ }^{2}$ Cumhuriyet University Faculty of Medicine, Department of General Surgery, Sivas, Turkey
Correspondence:

Fatma KAPLAN EFE

Health Sciences University Keçiören

Training and Research Hospital

Internal Medicine Clinic, Ankara

Turkey

e-mail: drefe.106@gmail.com

\section{Abstract}

Acute Physiology and Chronic Health Evaluation II (APACHE II) and Modified Charlson Index (MCI) are used to predict the fatality in intensive care units (ICU). We aimed to investigate the difference between these scores in the prediction of fatality in the medical intensive care unit. Our study is important because in our literature overview, this study is one of the rare studies that compares these scoring systems. 108 ICU patients included. In all subjects APACHE II and MCI performed. Procalcitonin, C-reactive protein(CRP) levels of patients were recorded. Patients were then grouped according to mechanically ventilated or not; mortality happened or not. Statistically significance found in age $(\mathrm{p}<0.045)$, mechanical ventilation, procalcitonin, CRP and MCI $(\mathrm{p}<0.001)$ about mortality. MCI sensitivity and specifity were higher than APACHE II in \%95 confidance interval. Area under curve in ROC analysis was CRP (0.728), Procalcitonin (0.719), MCI (0.686), APACHE II (0.665) respectively. Our study demonstrates that the Modified Charlson Index combined with procalcitonin and CRP can be used for predicting mortality in medical ICU as well as APACHE II

Keywords: APACHE II, Modified Charlson indeksi, Dahili yoğun bakım ünitesi, Prokalsitonin, C-reaktif protein

\section{Özet}

Acute Physiology and Chronic Health Evaluation II (APACHE II) ve Modifiye Charlson indeksi (MCI) yoğun bakımlarda mortalite öngörüsünde kullanılmaktadır. Biz bu skorlama sistemlerinin dahili yoğun bakımda yatan hastalardaki mortalite öngörüsünde aralarında fark olup olmadığını araştırdık. Çalışmamız dahili yoğun bakımda mortalite öngörüsünde bu iki skorlama sistemini karșılaștıran ilk çalıșma olması açısından önemlidir. Çalıșmaya 108 yoğun bakım hastası dahil edildi. Hastaların hepsine yatıșlarının ardından APACHE II ve MCI hesaplandı. Hastaların prokalsitonin ve C-reaktif protein(CRP)seviyeleri kaydedildi. Hastalar mekanik ventilasyon uygulanıp uygulanmaması ve mortalite oluşup oluşmaması açısından gruplandırıldı. Mortalite açısından yas $(\mathrm{p}<0,045)$, mekanik ventilasyon, prokalsitonin, CRP ve $\mathrm{MCI}$ istatiksel olarak anlamlı bulundu(p<0,001). MCI 'nin \% 95 güven aralığında sensitivitesi ve spesifitesi APACHE II ye göre daha yüksekti. ROC analizinde eğri altındaki alan ( Area under curve ) sırasıyla CRP için 0.728, Prokalsitonin için 0.719, MCI için 0.686, APACHE II için 0.665 di. Çalışmamız Modifiye Charlson indeksinin, procalcitonin ve CRP ile birlikte dahili yoğun bakımda mortaliteyi öngörmede APACHE II gibi kullanılabileceğini göstermiştir.

Anahtar Kelimeler: APACHE II, Modified Charlson indeksi, Dahili yoğun bakım ünitesi, Prokalsitonin, C-reaktif protein

Received 21.09.2021 Accepted 22.11.2021 Online published 23.11.2021 


\section{Introduction}

Predicting mortality and morbidity risks of hospitalised patients is important for plannig a sufficient treatment and patient care. For this purpose several scoring systems constituded for diseases using the features of related ilness as vital signs or laboratory and clinical findings.

Disease severity, age, nutrition, comorbidities, inflammation biomarkers, artificial ventilation support and infection status are the important factors determining intensive care unit (ICU) survival.

Various scoring systems are used to predicting mortality in ICU. Among them Acute Physiology and Chronic Health Evaluation II (APACHE II), mortality prediction model (MPM) and Simplified acute physiology score (SAPS ) are the most used scoring systems (1, 2).

Modified Charlson index (MCI) is also used for mortality prediction. MCI assesses patients according to 17 co-morbidities (3). Beside predicting the mortality and morbidity in ICU patients, MCI also used for assesing the mortality estimation in patients with sarcoma, orthotopic liver transplantation and pulmonary diseases (4-6). There is limited data about the prediction and risk assessment of the MCI for ICU patients (7). Furthermore there are only a few studies that compare MCI and APACHE II and have controversial results. Additionally a number of studies suggested interpreting MCI together with APACHE II could improve prognostic prediction (8) (9). Therefore, we tried to show the difference between MCI and APACHE II scoring systems for predicting hospital mortality among medical intensive care unit patients.

\section{Methods}

We evaluated patients hospitalised to Kecioren Research and Training Hospital intensive care unit between 01.01.2018 and 31.12.2018 after approval of local ethical committee. Patients older than 18, and diagnosed with diseases related to internal medicine were included in the study.
Coronary care patients, surgery and postoperative patients, neurological disease, and gynecology and obstetrics patients were excluded. The demographic data, procalcitonin, CRP, APACHE II, and MCI scores and supportive therapies were retrospectively collected from the hospital database.

\section{Statistical analysis}

Patients were grouped according to mortality and both groups were analysed for several demographic and clinical features . APACHE II scores were considered high risk if $>8$, and $\mathrm{MCI}$ scores were considered high risk if $>3$.

For statistical analysis, version 22.0 of SPSS was used. The normality of the distribution of continuous variables was tested by the Kolmogorov-Smirnov test. Variables shown as mean \pm SD if continuous and if discrete as median and IQR (Inter Quartile Ranges) 2575.AUC (area under curve) values calculated with ROC (Receiver Operating Characteristic) analysis. Chi-square test was applied to investigate the relationship between 2 categorical variables. Comparison of continous variables done by using Mann Whitney $\mathrm{U}$ test. $\mathrm{P}$ value $<0.05$ was accepted as statistically significant.

\section{Ethical Approval}

Health Sciences University Keçiören Education and Research Hospital Ethics Committee Permission was obtained with the letter dated 12.08.2020 and numbered 2156. Our research design was compatible with the Declaration of Helsinki, and was accepted by the Institutional Review Board (December 18, 2018; 43278876-929)

\section{Results}

108 cases were involved (n: 64 (53\%) female; 44 (47\%) male). Median age was 77(IQR: 67 $-82)$. Forty five $(41.7 \%)$ patients died and 63 patients were discharged. Fifty seven $(52,8 \%)$ patients were mechanically ventilated. Demographic data, laboratory findings and scoring points of patients were demonstrated in table 1. 
Table-1. General characteristics of patients

\begin{tabular}{|c|c|}
\hline $\begin{aligned} \operatorname{Sex} & n(\%) \\
& \text { Female } \\
\bullet & \text { Male }\end{aligned}$ & $\begin{array}{l}64(53) \\
44(47)\end{array}$ \\
\hline Age median (IQR\%25-75) & $77(67-82)$ \\
\hline $\begin{array}{cl}\text { Comorbidities } n(\%) \\
\text { - } & \text { Chronic Hypertension } \\
\text { - } & \text { Diabetes Mellitus } \\
\text { - } & \text { Chronic Kidney Disease }\end{array}$ & $\begin{array}{l}44(40.7) \\
44(40.7) \\
49(45.4)\end{array}$ \\
\hline $\begin{aligned} \text { Mortality } n(\%) \\
\text { - } \quad \text { Presence } \\
\text { - } \quad \text { Absence }\end{aligned}$ & $\begin{array}{l}45(41.7) \\
63(58.3)\end{array}$ \\
\hline $\begin{array}{c}\text { Mechanical Ventilation (\%) } \\
\qquad \quad \text { Presence } \\
\text { - } \quad \text { Absence }\end{array}$ & $\begin{array}{l}57(52.8) \\
51(47.2)\end{array}$ \\
\hline Procalcitonin median ( IQR\%25-75) & $0,67(0,11-5,4)$ \\
\hline CRP median ( IQR\%25-75) & $5,54(1,65-10-57)$ \\
\hline APACHE II median ( IQR\%25-75) & $29(22-36)$ \\
\hline Modified Charlson index median ( IQR\%25-75) & $7(5-9)$ \\
\hline $\begin{array}{ccc}\text { APACHE II } & \\
\cdot & 0-8 & n(\%) \\
- & 8< & n(\%)\end{array}$ & $\begin{array}{l}4(3) \\
104(96,3)\end{array}$ \\
\hline $\begin{array}{c}\text { Modified Charlson index } \\
\qquad \quad 0-3 n(\%) \\
\cdot \quad 3<n(\%) \\
\end{array}$ & $\begin{array}{l}10(9,3) \\
98(90,7)\end{array}$ \\
\hline
\end{tabular}

As shown in table 2; when both groups were compared for several parameters, it was found that there are statistically significance in age $(p<0,045) ; \quad$ mechanical ventilation, procalcitonin,crp, and modified charlson score. $(\mathrm{p}<0,001)$
When comparing the diagnostic performance of each scoring system and several markers for mortality, it was found that MCI was as useful as APACHE II. Sensitivity, specifity, positive predictive value and negative predictive value of MCI and APACHE II were displayed in table 3.

Table-2. Characteristics and laboratory data of patients according to Mortalitiy

\begin{tabular}{|c|c|c|c|}
\hline & Mortalitiy(+) & Mortalitiy(-) & PValue \\
\hline $\begin{array}{c}\operatorname{Sex} n(\%) \\
\bullet \quad \text { Female }\end{array}$ & $28(62,2)$ & $36(57,1)$ & \multirow[t]{2}{*}{0,5} \\
\hline - $\quad$ Male & $17(37.8)$ & $27(42.9)$ & \\
\hline Age (IQR\%25-75) & $78(74,5-85,5)$ & $76(64-81)$ & 0.045 \\
\hline $\begin{array}{l}\text { Comorbidities } n(\%) \\
\bullet \quad \text { Chronic Hypertension }\end{array}$ & $25(55,6)$ & $32(50,8)$ & 0,6 \\
\hline Diabetes Mellitus & $19(42,2)$ & $25(39,7)$ & 0,7 \\
\hline
\end{tabular}




\begin{tabular}{|c|c|c|c|}
\hline - Chronic Kidney Disease & $25(55,6)$ & $24(38,1)$ & 0,07 \\
\hline $\begin{array}{l}\text { Mechanical Ventilation (\%) } \\
\qquad \quad \text { Presence }\end{array}$ & $43(95,6)$ & $14(22,2)$ & \multirow{2}{*}{$<0.001$} \\
\hline - Absence & $2(4,4)$ & $49(77,8)$ & \\
\hline Procalcitonin ( IQR\%25-75) & $3,24(0,35-12,83)$ & $0,33(0,01-1,50)$ & $<0.001$ \\
\hline CRP ( IQR\%25-75) & $8,68(5,03-14,9)$ & $4,16(1,3-8,53)$ & $<0.001$ \\
\hline \multicolumn{4}{|l|}{ APACHE II } \\
\hline - $\quad 0-8 \quad n(\%)$ & $2(4,4)$ & $2(3,2)$ & \multirow[b]{2}{*}{0.55} \\
\hline - $\quad 8<n(\%)$ & $43(95,6)$ & $61(96,8)$ & \\
\hline \multirow{2}{*}{$\begin{array}{c}\text { Modified Charlson index } \\
\qquad \quad 0-3 n(\%) \\
\bullet \quad 3<n(\%)\end{array}$} & $1(2,2)$ & $9(14,3)$ & \multirow[t]{2}{*}{$\mathbf{0 . 0 3}$} \\
\hline & $44(97,8)$ & $54(85,7)$ & \\
\hline
\end{tabular}

Table-3. Comparison of Apache 2 and Modified Charlson scores findings \% (95\%CI)

\begin{tabular}{lcc}
\hline & APACHE 2 & M.CHARLSON \\
\hline Sensitivity & $95,56(84,85-99,46)$ & $97,78(88,23-99,94)$ \\
Specificity & $3,17(0,39-11)$ & $14,29(6,75-25,39)$ \\
Accuracy & $41,67(32,25-51,55)$ & $49,07(39,33-58,87)$ \\
PLR & $0,99(0,91-1.07)$ & $1,14(1,02-1,27)$ \\
NLR & $1,4(0,2-9,57)$ & $0,16(0,02-1,18)$ \\
PPV & $41,35(39,49-43,23)$ & $44,9(42,19-47,6)$ \\
NPV & $50(12,76-87,24)$ & $90(54,16-98,56)$ \\
PLR: Positive likelihood ratio, NLR: Negative likelihood ratio, PPV: positive predictive value, NPV: Negative predictive value \\
\hline
\end{tabular}

\section{Discussion}

Scoring systems predict the risk of mortality by using symptoms, physical examination findings and the results of the laboratory tests . Therefore our aim was to establish a scoring system that is valid and reliable. The objective of our research was to compare the performance of MCI and APACHE II systems for predicting the mortality of ICU patients. Our study's importance and difference from previous studies is that it was one of the few studies carried out in a medical intensive care unit. According to our knowledge, most of these studies in the literature were done in surgical and anesthesia intensive care units.

In our study, age, and mechanical ventilation were associated with mortality as expected. Procalcitonin, CRP, and MCI were associated significantly with mortality, however APACHE II was not associated with mortality. MCI was more sensitive and specific than APACHE II, the accuracy was superior in MCI compared to APACHE II (\%95 confidence interval) .Table 3

There are conflicting results regarding the comparison of scoring systems in the literature. Evran et al. reported that age was significantly linked with higher mortality rates (10). One study determined APACHE II had a more correct evaluation system for fatality contrast to ODIN(organ dysfunction and infection system ), SAPS2 and MCI in geriatric patients undergoing emergency abdominal surgery (11). Quach et al.found that the MCI had not enough accuracy as APACHE II for prognosticating hospital mortality in an intensive care unit (12). APACHE II was found a better option for betokening to sepsis related deaths (13).However Dosset et al. did not suggest APACHE II for the trauma associated 
mortality prediction in the first 24 hours (14). In another study APACHE III was found more sensitive and specific than APACHE II in predicting mortality(15). PIRO (predisposition, insult, response, organ dysfunction) score, APACHE II and MEDS(mortality in emergency department sepsis) were similar in forecasting mortality in sepsis cases (16). Another study that analysed the association between mortality and procalcitonin, CRP, and SOFA(sequential organ failure assessment ) score in ICU, showed that both procalcitonin and CRP were associated with mortality(17).In sepsis patients Chien-Chang Lee et al showed MEDS score was the most specific and procalcitonin was the most sensitive in predicting mortality(18). Similar to our results some studies showed MCI can be useful in mortality prediction. A study comparing MCI and APACHE II found that

\section{REFERENCES}

1. Vincent JL, Moreno R. Clinical review: scoring systems in the critically ill. Crit Care. 2010;14:207.

2. Higgins TL, Teres D, Copes WS, Nathanson BH, Stark M, Kramer AA. Assessing contemporary intensive care unit outcome: an updated Mortality Probability Admission Model (MPM0-III). Crit Care Med. 2007;35:827-35.

3. Charlson ME, Pompei P, Ales KL, MacKenzie CR. A new method of classifying prognostic comorbidity in longitudinal studies: development and validation. J Chronic Dis. 1987;40:373-83.

4. Eraslan Doganay G, Cirik MO. Determinants of prognosis in geriatric patients followed in respiratory ICU; either infection or malnutrition. Medicine. 2021;100:e27159.

5. Gupta R, Heshami N, Jay C, Ramesh N, Song J, Lei $\mathrm{X}$, et al. Predictors of survival in patients with sarcoma admitted to the intensive care unit. Clinical sarcoma research. 2016;6:12

6. Niewiński G, Graczyńska A, Morawiec S, Raszeja-Wyszomirska J, Wójcicki M, Zieniewicz K, Główczyńska R, Grą M. Renaissance of Modified Charlson Comorbidity Index in Prediction of Short- and Long-Term Survival After Liver Transplantation? Med Sci Monit. 2019 ;25:4521-26.

7. Needham DM, Scales DC, Laupacis A, Pronovost PJ. A systematic review of the Charlson comorbidity index using Canadian administrative databases: a perspective on risk adjustment in critical care research. J Crit Care. 2005;20:12-9. these scoring systems are similar in short and prolonged-term mortality for ICU patients (19). Violante Di Donato et al. concluded that MCI could be used as a prognostic factor for surgery needed vulvar cancers(20). Sampada B.Desai et al found that MCI can predict postsurgical adverse events. Like our results there was a high negative predictive value for adverse events(21). Another study in patients undergoing prostatectomy MCI was an effective prognostic factor(22). A study in kidney transplant recipients suggested MCI in clinical practice to stratify the mortality hazard in patients who undergo renal transplantation(23).However another study showed no association between MCI and mortality (24)

In decision we demonstrated that MCI combined with procalcitonin and CRP can be used reliably for predicting mortality instead of APACHE II in medical ICU cases.

8. Poses RM, McClish DK, Smith WR, Bekes C, Scott WE. Prediction of survival of critically ill patients by admission comorbidity. $J$ Clin Epidemiol. 1996;49:743-7.

9. Norena M, Wong H, Thompson WD, Keenan SP, Dodek PM. Adjustment of intensive care unit outcomes for severity of illness and comorbidity scores. J Crit Care. 2006;21:142-50.

10. Evran T SS, Gurses E, Various scoring systems for predicting mortality in Intensive Care Unit. Niger J Clin Pract. 2016;19:530-4.

11. Özban M, Birsen O, Şenel M, Özden A, Kabay B. The analysis of scoring systems predicting mortality in geriatric emergency abdominal surgery. Ulus Travma Acil Cerrahi Derg. 2015;21:182-6

12. Quach S DAH, Faris P. et al. A comparison between the APACHE II and Charlson Index Scorefor predicting hospital mortality in critically ill patients. BMC Health Services Research 2009;9:129.

13. Sadaka F, EthmaneAbouElMaali C, Cytron MA, Fowler K, Javaux VM, O'Brien J. Predicting Mortality of Patients With Sepsis: A Comparison of APACHE II and APACHE III Scoring Systems. J Clin Med Res. 2017;9:907-10.

14. Dossett LA, Redhage LA, Sawyer RG, May AK. Revisiting the validity of APACHE II in the trauma ICU: improved risk stratification in critically injured adults. Injury. 2009;40:993-8.

15. Haq A, Patil S, Parcells AL, Chamberlain RS. The Simplified Acute Physiology Score III Is Superior 
to the Simplified Acute Physiology Score II and Acute Physiology and Chronic Health Evaluation II in Predicting Surgical and ICU Mortality in the "Oldest Old". Curr Gerontol Geriatr Res. 2014;2014:934852.

16. H. Bryant Nguyen CVG, Michael Batech et al. Comparison of Predisposition, Insult/Infection, Response, and Organ Dysfunction, Acute Physiology And Chronic Health Evaluation II, and Mortality in Emergency Department Sepsis in patients meeting criteria for early goal-directed therapy and the severe sepsis resuscitation bundle. Journal of Critical Care 2012;27:362-9.

17. Castelli GP PC, Cita M, et al. Procalcitonin, Creactive protein, white blood cells and SOFA score in ICU: diagnosis and monitoring of sepsis. Minerva Anestesiologica 2006;72:69-80.

18. Lee CC, Chen SY, Tsai CL, Wu SC, Chiang WC, Wang JL, et al. Prognostic value of mortality in emergency department sepsis score, procalcitonin, and C-reactive protein in patients with sepsis at the emergency department. Shock. 2008;29:322-7.

19. Christensen S, Johansen MB, Christiansen CF, Jensen R, Lemeshow S. Comparison of Charlson comorbidity index with SAPS and APACHE scores for prediction of mortality following intensive care. Clin Epidemiol. 2011;3:203-11.

20. Violante Di Donato PZ, Bracchi C.et al The ageadjusted Charlson comorbidity index as a predictor of survival in surgically treated vulvar cancer patients. J Gynecol Oncol 2019; e6.

21. Dessai SB, Fasal R, Dipin J, Adarsh D, Balasubramanian S. Age-adjusted charlson comorbidity index and 30-day morbidity in pelvic surgeries. South Asian J Cancer. 2018;7:240-3.

22. Park JW, Koh DH, Jang WS, Lee JY, Cho KS, Ham WS, et al. Age-adjusted Charlson Comorbidity Index as a prognostic factor for radical prostatectomy outcomes of very high-risk prostate cancer patients. PLoS One. 2018;13:e199365.

23. J.Y. Park MHK, E.J. Bae, et.al. Comorbidities Can Predict Mortality of Kidney Transplant Recipients Comparison With the Charlson Comorbidity Index. Transplantation Proceedings. 2018;50:1068-73.

24. Meireles M. MA, Lopes J. et al. Age-adjusted Charlson Comorbidity Index Does Not Predict Outcomes in Patients Submitted to Noninvasive Ventilation. Arch Bronconeumol 2018;54:503-9 